Egyptian Journal of Aquatic Biology \& Fisheries

Zoology Department, Faculty of Science,

Ain Shams University, Cairo, Egypt.

ISSN $1110-6131$

Vol. 24(4): 373 - 390 (2020)

www.ejabf.journals.ekb.eg

\title{
Physiological and histological alterations in fishes induced by pollution in Lake Nasser and the potential human risk assessment
}

\author{
Sally M. Salaah ${ }^{1 * *}$, Dalia M. El-Gaar ${ }^{1}$ \\ ${ }^{1}$ National Institute of Oceanography and Fisheries (NIOF), Cairo, Egypt. \\ Corresponding Author:sallysalaah84@gmail.com
}

\section{ARTICLE INFO}

Article History:

Received: June 4, 2020

Accepted: June 30, 2020

Online: July 2020

Keywords:

Lake Nasser;

O. niloticus;

S. galilaeus;

Heavy metals;

Risk assessment;

Hematology;

Biochemical analyses;

Histology;

Fish health.

\section{ABSTRACT}

Lake Nasser ecosystem has undergone many changes that decline species diversity; the lakes' fisheries also have experienced a decrease during the last 10 years disturbing its prospect for sustainability. Therefore, this study aimed to evaluate and compare the effect of water contaminants on $O$. niloticus and S. galilaeus inhabiting different locations of Lake Nasser. Heavy metals (HM) accumulation in the liver, gills and muscles of both O. niloticus and S. galilaeus generally arranged in the following order; $\mathrm{Fe}>\mathrm{Mn}>\mathrm{Zn}>\mathrm{Cd}>\mathrm{Cu}$. The metal pollution index (MPI) in the studied organs pursued the order: liver $>$ gill $>$ muscle. While the hematological and biochemical indices of $O$. niloticus and S. galilaeus exhibited a significant alteration due to inhabiting stressful conditions. Moreover, pathological changes were observed in muscles of both fish species from different sampling sites. The present study opined that $S$. galilaeus are more resistant than $O$. niloticus to environmental stress, while $O$. niloticus are more sensitive to aquatic pollutants. Moreover, there was a significant alteration in fish health, as well as adverse health effects, for habitual consumers of both fish species from S4.

\section{INTRODUCTION}

Lake Nasser is one of the longest man-made lakes in the world; it was formed after the construction of Aswan High Dam. Furthermore it considered the fundamental water bank of Egypt; which provides more than $95 \%$ of freshwater needs (Ali et al., 2016). The total surface area is $6276 \mathrm{~km}^{2}, 5237 \mathrm{~km}^{2}$ represents Lake Nasser and $1039 \mathrm{~km}^{2}$ in the northern part of Sudan is known as Lake Nubia (Heikal, 2010).

The lake bank is extremely irregular with several terminal extensions known as khors that is representing about $79 \%$ of total lake surface. Khors are the favorite habitat for fish; therefore Khors are important in fish production (El-Shabrawy and Dumont, 2003). Many previous studies investigated the ecology and morphology of Lake Nasser (Latif, 1984; Khalifa et al., 2000; El-Shabrawy, 2014). The Water quality of the Lake Nasser is influenced by many factors such as; water levels, thermal stratification, water circulation and pollutants (El-Shabrawy, 2014). 
Lake Nasser fisheries have undergone a steady decrease during the last 10 years obscuring its potential for sustainability. In 1976, Latif recorded 58 species in Lake Nasser. However currently, the fisheries depend only upon a limited number of species which are adapted well to the new conditions and indeed become the main species in the Lake (Khalifa et al., 2000). Moreover, Bishai et al. (2000) reported that, the eutrophic state of the lake discriminated locally, vertically and seasonally, as the phytoplankton crop increased southwards. Likewise, El-Far et al. (2020) recorded only thirty-four fish species in the Lake where six of them were dominant, namely; Oreochromis niloticus, Sarothrodon galilaeus, Coptodon zillii, Lates niloticus, Alestes baramoze, and Hydrocynus vittitus, also reported a dramatic change in the lake ecosystem and species diversity, that Some species are now limited to the southern side of the lake, while others have disappeared completely. Fish are directly affected by their environment, only a thin epithelial membrane is the barrier between fish blood and water. Fish are very vulnerable to water chemical and physical changes which alter their blood components (Çelik et al., 2012).

Heavy metals (HM) generally exist in aquatic environments at low levels but the anthropogenic activities have elevated their levels, which stimulate environmental concern in lakes (Ntakirutimana et al., 2013). HM are non-biodegradable; they are not expelled from water due to self-purification, as soon as they are discharged into water systems, they adsorbed on sediment, accumulate in aquatic animals and get into the food chain (Loska and Wiechula, 2003), consequently fish absorb and accumulate HM from water and diet in tissues.

Blood parameters are pathophysiological indicators of the whole body, which is known to display pathological changes before morphological symptoms of toxicity or diseases. Biochemical characteristics of blood are the most important tool to diagnose fish health when exposed to pollutants or stress conditions (Suvetha et al., 2010).

To our knowledge, no study has been conducted to investigate the impact of Lake Nasser pollution on the fish health and human risk assessment. Therefore, this study aimed to evaluate and compare the effect of water contaminants on O. niloticus and $S$. galilaeus inhabiting different locations of Lake Nasser, through the hematological, biochemical and histological investigations.

\section{MATERIALS AND METHODS}

\section{Area of study}

Study area: Sampling was carried out in March 2019 from two selected khors of Lake Nasser, El-Ramla and Toushka (Table 1). Two sites were selected for each khor, in the entrance and middle of khors.

\section{Sample collection}

Samples of $O$. niloticus and $S$. galilaeus were collected from different sites by the assistant of local fishermen during March 2019, with average weight $30 \pm 10 \mathrm{~g}$ for $O$. 
niloticus and $361 \pm 100 \mathrm{~g}$ for $S$. galilaeus. Blood samples were collected by caudal severance, and separated into two aliquots. The first aliquot was collected in tubes with EDTA and stored at $4{ }^{\circ} \mathrm{C}$, for hematological assessments, while the other part was left to clot for $30 \mathrm{~min}$ at room temperature, the clotted samples were then centrifuged at $1000 \mathrm{xg}$ at $4^{\circ} \mathrm{C}$ for $10 \mathrm{~min}$, and the obtained serum was stored at $-20^{\circ} \mathrm{C}$ for further analysis.

Table (1): Sampling sites and GPS data of Lake Nasser.

\begin{tabular}{clll}
\hline Site & \multicolumn{1}{c}{ Location } & Latitude & Longitude \\
\hline S1 & Intrance of khor Toushka & $22^{\circ} 32^{\prime} 65,63^{\prime \prime} \mathrm{N}$ & $31^{\circ} 75^{\prime} 56,73^{\prime \prime} \mathrm{E}$ \\
S2 & Middle of khor Toushka & $22^{\circ} 32^{\prime} 58,48^{\prime \prime} \mathrm{N}$ & $31^{\circ} 77^{\prime} 95,32^{\prime \prime} \mathrm{E}$ \\
S3 & Interance of khor El-Ramla & $23^{\circ} 90^{\prime} 61,11^{\prime \prime} \mathrm{N}$ & $32^{\circ} 84^{\prime} 75,34^{\prime \prime} \mathrm{E}$ \\
S4 & Middle of khor El-Ramla & $23^{\circ} 88^{\prime} 07^{\prime \prime} \mathrm{N}$ & $32^{\circ} 81^{\prime} 42,73^{\prime \prime} \mathrm{E}$ \\
\hline
\end{tabular}

\section{Hematological indices:}

Total red blood cells count (RBC) was done using an improved Neubaur hemocytometer (Shah and Altindağ, 2004). Hemoglobin (Hb) and Hematocrit (Hct) were determined using Cyanmethemoglobin and microhematocrit methods (Blaxhall and Daisley, 1973). Blood indices were calculated using the formulae mentioned by Hrubec and Smith (2000).

\section{Biochemical parameters:}

Serum glucose levels were measured using colorimetric method described by Tietz (1995). Total serum protein was assessed according to Tietz (1994). Albumin was measured colorimetrically according to the method described by Doumas et al. (1971). Aspartate aminotransferase (AST) and Alanine aminotransferase (ALT) activity was measured according to IFCC (1986) Kinetic method. Serum creatinine was determined according to Tietz (1986), while serum urea and uric acid were measured enzymatically according to Tietz (1990). The total lipids were estimated using Frings and Dunn (1970) method. Serum potassium and sodium levels were estimated according to Sunderman and Sunderman (1958) and Trinder (1951), respectively.

HM analysis:

portions of fish tissues (muscles, liver, and gills) were dissected for analysis from $O$. niloticus and $S$. galilaeus, separately. Dissected samples were transferred to Teflon beaker for acid digestion, as well as prepare the sample for heavy metal analysis according to the method described by Ghazaly (1988). Fe, Mn, $\mathrm{Zn}, \mathrm{Cu}$, and $\mathrm{Cd}$ concentrations in fish tissues were analyzed by atomic absorption mode GBC SavantaAA AA with GF 5000 graphite furnace.

Metal Pollution Index (MPI).

MPI was calculated to indicate the overall metal load in fish tissues using the following formula according to Usero et al. (1997):

$$
\text { MPI }=\left(M_{1} \times M_{2} \times M_{3} \times \cdots \times\right)^{1 / n}
$$

where $M_{n}$ is the mean concentration of metal $n(\mathrm{mg} / \mathrm{kg}$ dry weight) in the studied tissue. 


\section{Human Risk Assessment.}

The risk assessment procedures were performed according to USEPA (2000) with abbreviation. The level of exposure caused by oral ingesting of HM in fish edible tissues was expressed by calculating the average daily intake of a specific chemical over a lifetime (ADD) using the following equation:

$$
\mathrm{ADD}(\mathrm{mg} / \mathrm{kg} / \text { day })=\mathrm{C}_{m} \times \mathrm{IR} / \mathrm{BW} \text {, }
$$

where $\mathrm{C}_{m}$ is the mean metal concentration in fish muscle ( $\mathrm{mg} / \mathrm{kg}$ dry weight), IR is the ingestion rate $(0.0312$ and $0.1424 \mathrm{~kg} /$ day for normal and habitual fish consumers, respectively), BW is the body weight (assumed as $70 \mathrm{~kg}$ for normal adults) Risk was assessed by calculating the hazard index (HI; index of adverse health effects from intake of specific contaminant in food). HI is expressed as the ratio of the ADD to the oral reference dose of the metal according to the following equation proposed by USEPA (2000):

Hazard Index = ADD / Oral RfD,

where oral RfD is the oral reference dose of the metal $(\mathrm{mg} / \mathrm{kg} / \mathrm{day})$ based on the safe upper level of metal's oral intake for an adult human with average body weight of $70 \mathrm{~kg}$. The oral RfD for $\mathrm{Cu}, \mathrm{Zn}, \mathrm{Mn}, \mathrm{Cd}$, and $\mathrm{Fe}$ is $0.04,0.3,0.14,0.001$, and $0.7 \mathrm{mg} / \mathrm{kg} / \mathrm{day}$, respectively (USEPA, 2015). When $\mathrm{HI} \geq 1.0$, it may be assumed that adverse health effects are expected. The cumulative risk effect of all metals was calculated as the sum of HI values (USEPA, 2002).

\section{Histopathological examination:}

Immediately after dissection of the studied fish, parts of liver, gills and muscles were carefully removed and fixed in $10 \%$ formalin at $4{ }^{\circ} \mathrm{C}$, for 48 hours then the samples were dehydrated in ascending grades of alcohol and cleared in xylene. The fixed tissues were embedded in paraffin wax and sectioned into five micrometers thick using Euromex Holland Microtome, and then stained according to Harris Hematoxylin and Eosin method. Finally, the sections were examined microscopically and photographed by a microscopic camera according the methods cited by Tayel et al. (2018).

\section{Statistical analysis}

The results were expressed as Mean \pm S.E of 6 fish, using a Microsoft Excel sheet on Windows 2010. The differences among treatments were analyzed using a one way Analysis of Variance (ANOVA) followed by a Duncan Multiple Range Test for multiple comparisons of the means. The statistical significance was set at $\mathrm{P}<0.05$ using SPSS for Windows version 23.0 (SPSS, Michigan Avenue, Chicago, IL, USA).

\section{RESULTS AND DISCUSSION}

Lake Nasser is the tank of fresh water in Egypt. However, there are no direct pollution sources of HM discharging into Nasser Lake. On the other hand, the lake receives $\mathrm{HM}$ via the anthropogenic activity of fishermen sewage, fishing boats, cruise ships, and others which disposed directly into the Sudanese Main Nile (Darwish, 2013). 
Fishes are located at the top of the aquatic food chain, and they normally accumulate HM from food, water, and sediments (Zhao et al., 2012); therefore, fishes are major source of HM in food (Sivaperumal et al., 2007).

High accumulation levels of HM in fish tissues have induced sever adverse effects on human health (Castro-González and Méndez-Armenta, 2008), such as liver damage, renal failure, cardiovascular diseases, and even death (Al-Busaidi et al., 2011). Therefore, monitoring and management should be considered constantly to help the decision-maker to assess the health of aquatic environment of the lake (Agrama, 2014).

Metals are distributed unequally in fish tissues, but accumulate mainly in active tissues such as kidney, liver, and gill (Yacoub and Gad, 2012), while muscle exhibits lower HM levels due to its weak affinity of binding proteins and enzymes (Papagiannis et al., 2004; Bayomy et al., 2015). Fish accumulate HM through gills or ingestion of contaminated food; moreover, the accumulation of metals in the aquatic organism's tissues could be used as indicator for pollution, since it specific to species and mode of exposure (Jarić et al., 2011).

The metal concentration and pollution index (MPI) of $O$. niloticus and $S$. galilaeus were given in Table (2). The HM accumulation in liver, gills and muscles of both $\mathrm{O}$. niloticus and $S$. galilaeus generally arranged in the following order; $\mathrm{Fe}>\mathrm{Mn}>\mathrm{Zn}>\mathrm{Cd}>$ $\mathrm{Cu}$.

According to Table (2) the levels of $\mathrm{Fe}, \mathrm{Zn}, \mathrm{Mn}$ and $\mathrm{Cu}$ were within the permissible limits in liver, gills and muscles of both fish species. While $\mathrm{Cd}$ levels exceeded the permissible limits in liver and gills, which are non-edible parts, in both $O$. niloticus and $S$. galilaeus (WHO, 1989). In the present study, the higher levels of HM was recorded at S4 in tissues from both fish species, that in line with Hussein and EI Shafi (2005) who reported that the HM levels in the northern part of the lake were much higher than the southern part.

The MPI of the studied organs followed the order: liver $>$ gill $>$ muscle which gives a better idea about the target tissues for HM accumulation in O. niloticus and $S$. galilaeus fish. The results clearly indicate that each fish species, as well as their tissues, have different accumulating capacity of HM. Moreover, S. galilaeus recorded higher HM concentration and MPI in tissues than O. niloticus inhabiting the same site.

The hazard index (HI) calculations integrate both the HM level in the edible tissues of fish and the human consumption rate of these tissues to perform a risk classification. In hazard identification, available data on biological endpoints are used to determine if a material is likely to pose a hazard to human. Fish consumption data is necessary for estimating the human health impact of consuming chemically polluted fish (Copat $\boldsymbol{e t}$ al., 2012). Based on the estimations used in this study (Table 3), the habitual consumption of both fish species recorded a health risk at S4 and at S2 for $S$. galilaeus only.

It is well recognized that both natural and man-made chemicals negatively affect fishes. Moreover, environmental pollution may change the count and structure of 
blood indices (Katalay and Parlak, 2004). So the study of the hematological indices in fish are the most commonly used tool to diagnose fish health, as it's usually used for the detection of pathophysiological changes due to several stress conditions (Nussey et al., 1995).

Table (2): Metal concentrations ( $\mathrm{mg} / \mathrm{kg}$ dry weight) in tissues of $O$. niloticus and $S$. galilaeus from Lake Nasser and metal pollution index (MPI).

\begin{tabular}{cccccccccccccc} 
& & \multicolumn{4}{c}{ O. niloticus } & \multicolumn{4}{c}{ S. galilaeus } \\
\cline { 3 - 15 } & & Fe & Mn & Zn & Cu & Cd & MPI & Fe & Mn & Zn & Cu & Cd & MPI \\
\hline \multirow{3}{*}{ S1 } & Liver & 39.3 & 24.35 & 1.13 & 0.04 & 0.45 & 1.82 & 39.8 & 25.26 & 2.12 & 0.06 & $0.52^{*}$ & 2.38 \\
& Gill & 25.05 & 8.41 & 0.34 & 0.04 & 0.47 & 1.07 & 35.22 & 9.58 & 0.53 & 0.05 & 0.47 & 1.25 \\
& Muscle & 23.65 & 5.8 & 0.68 & 0.04 & 0.44 & 0.92 & 28.81 & 6.61 & 0.37 & 0.06 & 0.32 & 1.03 \\
& Liver & 40.93 & 25.46 & 1.51 & 0.12 & 0.32 & 2.28 & 40.04 & 28.49 & 1.27 & 0.08 & $0.73^{*}$ & 2.45 \\
S2 & Gill & 38.33 & 13.8 & 0.57 & 0.05 & $0.60^{*}$ & 1.58 & 47.383 & 12.38 & 0.65 & 0.05 & $0.61^{*}$ & 1.65 \\
& Muscle & 30.05 & 6.48 & 0.32 & 0.03 & 0.23 & 0.88 & 36.057 & 6.61 & 0.48 & 0.06 & 0.42 & 1.24 \\
& Liver & 45.7 & 26.55 & 1.7 & 0.06 & $0.99^{*}$ & 2.58 & 48.613 & 34.69 & 2.65 & 0.14 & $1.33^{*}$ & 3.88 \\
S3 & Gill & 47.21 & 10.08 & 0.87 & 0.07 & $0.74^{*}$ & 1.84 & 41.78 & 20.93 & 1.19 & 0.08 & $0.66^{*}$ & 2.24 \\
& Muscle & 41.9 & 5.56 & 0.40 & 0.05 & 0.35 & 1.08 & 39.38 & 6.6 & 0.56 & 0.07 & $0.50^{*}$ & 1.38 \\
& Liver & 60.74 & 32.52 & 1.4 & 0.15 & $1.38^{*}$ & 3.58 & $69.73 *$ & 30.07 & 3.56 & 0.17 & $1.75^{*}$ & 4.69 \\
S4 & Gill & 53.23 & 14.56 & 0.89 & 0.08 & $0.94^{*}$ & 2.23 & $60.10^{*}$ & 26.82 & 1.41 & 0.14 & $1.12^{*}$ & 3.25 \\
& Muscle & 43.22 & 6.39 & 0.51 & 0.05 & 0.48 & 1.29 & 44.02 & 7.6 & 0.82 & 0.06 & 0.5 & 1.56 \\
\hline
\end{tabular}

*exceeded the maximum permissible limit (MPL) according to WHO (1989); 50, 40, 30, and $0.5 \mathrm{for} \mathrm{Fe,}$ $\mathrm{Zn}, \mathrm{Cu}$, and $\mathrm{Cd}$, respectively.

Table (3): Hazard index (HI) and the cumulative risk effect for normal and habitual consumers of $O$. niloticus and $S$. galilaeus from Lake Nasser.

\begin{tabular}{|c|c|c|c|c|c|c|c|c|c|c|c|c|c|}
\hline & \multicolumn{6}{|c|}{ O. niloticus } & \multicolumn{6}{|c|}{ S. galilaeus } \\
\hline & & $\mathrm{Fe}$ & $\mathrm{Cu}$ & Mn & $\mathbf{Z n}$ & Cd & $\begin{array}{l}\text { Cumulative } \\
\text { risk effect }\end{array}$ & $\mathbf{F e}$ & $\mathbf{C u}$ & Mn & $\mathbf{Z n}$ & Cd & $\begin{array}{c}\text { Cumulative } \\
\text { risk effect }\end{array}$ \\
\hline \multirow{2}{*}{ S1 } & normal & 0.015 & 0.0004 & 0.018 & 0.0004 & 0.209 & 0.243 & 0.018 & 0.0007 & 0.021 & 0.0004 & 0.143 & 0.183 \\
\hline & habitual & 0.072 & 0.002 & 0.084 & 0.002 & 0.958 & 0.618 & 0.084 & 0.003 & 0.096 & 0.002 & 0.653 & 0.838 \\
\hline \multirow{2}{*}{ S2 } & normal & 0.024 & 0.0004 & 0.021 & 0.0005 & 0.238 & 0.283 & 0.023 & 0.0007 & 0.021 & 0.0007 & 0.420 & 0.465 \\
\hline & habitual & 0.111 & 0.002 & 0.094 & 0.002 & 0.484 & 0.693 & 0.105 & 0.003 & 0.096 & 0.003 & 0.854 & $1.061^{*}$ \\
\hline \multirow{2}{*}{ S3 } & normal & 0.027 & 0.006 & 0.018 & 0.0005 & 0.156 & 0.2021 & 0.0250 & 0.0008 & 0.021 & 0.0008 & 0.242 & 0.2896 \\
\hline & habitual & 0.122 & 0.003 & 0.081 & 0.002 & 0.712 & 0.921 & 0.114 & 0.004 & 0.096 & 0.004 & 1.105 & 1.323 \\
\hline \multirow{2}{*}{ S4 } & normal & 0.028 & 0.0006 & 0.0203 & 0.0007 & 0.2006 & 0.4302 & 0.028 & 0.0007 & 0.024 & 0.001 & 0.232 & 0.2859 \\
\hline & habitual & 0.126 & 0.003 & 0.093 & 0.003 & 0.915 & $1.14^{*}$ & 0.128 & 0.003 & 0.11 & 0.006 & 1.059 & $1.306^{*}$ \\
\hline
\end{tabular}


Table (4): The hematological indices of $O$. niloticus and $S$. galilaeus from Lake Nasser.

\begin{tabular}{|c|c|c|c|c|c|c|c|c|}
\hline & \multicolumn{2}{|c|}{ S1 } & \multicolumn{2}{|c|}{ S2 } & \multicolumn{2}{|c|}{ S3 } & \multicolumn{2}{|c|}{ S4 } \\
\hline & $\begin{array}{c}O . \\
\text { niloticus }\end{array}$ & $\begin{array}{c}S . \\
\text { galilaeus }\end{array}$ & $\begin{array}{c}O . \\
\text { niloticus }\end{array}$ & $\begin{array}{c}S . \\
\text { galilaeus }\end{array}$ & $\begin{array}{c}O . \\
\text { niloticus }\end{array}$ & $\begin{array}{c}S . \\
\text { galilaeus }\end{array}$ & $\begin{array}{c}O . \\
\text { niloticus }\end{array}$ & $\begin{array}{c}S . \\
\text { galilaeus }\end{array}$ \\
\hline $\begin{array}{c}\text { RBCs } \\
\left(\times 10^{6} / \mu \mathrm{L}\right)\end{array}$ & $\begin{array}{c}1.98 \\
\pm 0.02^{\mathrm{a}}\end{array}$ & $\begin{array}{c}1.89 \\
\pm 0.02^{\mathrm{a}}\end{array}$ & $\begin{array}{c}1.79 \\
\pm 0.03^{\mathrm{b}}\end{array}$ & $\begin{array}{c}1.57 \\
\pm 0.02^{\mathrm{b}}\end{array}$ & $\begin{array}{c}1.70 \\
\pm 0.03^{\mathrm{c}}\end{array}$ & $\begin{array}{r}1.48 \\
\pm 0.03^{\mathrm{c}}\end{array}$ & $\begin{array}{c}1.41 \\
\pm 0.02^{\mathrm{d}}\end{array}$ & $\begin{array}{c}1.34 \\
\pm 0.02^{\mathrm{d}}\end{array}$ \\
\hline $\mathbf{H b}(\xi$ & $\begin{array}{c}7.48 \\
\pm 0.13^{\mathrm{a}}\end{array}$ & $\begin{array}{c}6.81 \\
\pm 0.17^{\mathrm{a}}\end{array}$ & $\begin{array}{c}7.16 \\
\pm 0.24^{\mathrm{a}}\end{array}$ & $\begin{array}{c}6.64 \\
\pm 0.17^{\mathrm{ab}}\end{array}$ & $\begin{array}{c}7.01 \\
\pm 0.22^{\mathrm{a}}\end{array}$ & $\begin{array}{c}6.56 \\
\pm 0.19^{\mathrm{ab}}\end{array}$ & $\begin{array}{c}6.53 \\
\pm 0.29^{\mathrm{b}}\end{array}$ & $\begin{array}{c}6.12 \\
\pm 0.16^{\mathrm{b}}\end{array}$ \\
\hline HCT (\%) & $\begin{array}{c}22.65 \\
\pm 0.25^{\mathrm{a}}\end{array}$ & $\begin{array}{l}21.36 \\
\pm 0.43^{\mathrm{a}}\end{array}$ & $\begin{array}{c}19.61 \\
\pm 0.23^{\mathrm{c}}\end{array}$ & $\begin{array}{c}18.07 \\
\pm 0.30^{\mathrm{b}}\end{array}$ & $\begin{array}{c}20.48 \\
\pm 0.30^{\mathrm{b}}\end{array}$ & $\begin{array}{c}16.90 \\
\pm 0.24^{\mathrm{c}}\end{array}$ & $\begin{array}{c}16.71 \\
\pm 0.31^{\mathrm{d}}\end{array}$ & $\begin{array}{c}16.01 \\
\pm 0.27^{\mathrm{d}}\end{array}$ \\
\hline MCV (fL) & $\begin{array}{c}87.69 \\
\pm 0.95^{\text {a }}\end{array}$ & $\begin{array}{c}89.72 \\
\pm 1.19^{\mathrm{ab}}\end{array}$ & $\begin{array}{c}85.94 \\
\pm 0.86^{\mathrm{a}}\end{array}$ & $\begin{array}{c}92.42 \\
\pm 1.21^{\mathrm{b}}\end{array}$ & $\begin{array}{r}85.89 \\
\pm 1.05^{\mathrm{a}}\end{array}$ & $\begin{array}{c}88.60 \\
\pm 0.92^{\mathrm{b}}\end{array}$ & $\begin{array}{c}82.18 \\
\pm 0.74^{\mathrm{ab}}\end{array}$ & $\begin{array}{c}87.01 \\
\pm 0.72^{b}\end{array}$ \\
\hline$\underset{\text { (pg/dL) }}{\text { MCH }}$ & $\begin{array}{c}36.30 \\
\pm 0.63^{\text {a }}\end{array}$ & $\begin{array}{c}49.69 \\
\pm 0.70^{\text {a }}\end{array}$ & $\begin{array}{c}34.89 \\
\pm 0.68^{\mathrm{ab}}\end{array}$ & $\begin{array}{c}41.18 \\
\pm 0.67^{\mathrm{b}}\end{array}$ & $\begin{array}{r}34.76 \\
\pm 0.64^{\mathrm{ab}}\end{array}$ & $\begin{array}{c}37.65 \\
\pm 0.48^{\mathrm{c}}\end{array}$ & $\begin{array}{c}34.01 \\
\pm 0.48^{\mathrm{b}}\end{array}$ & $\begin{array}{c}36.80 \\
\pm 0.62^{\mathrm{c}}\end{array}$ \\
\hline $\begin{array}{c}\text { MCH C } \\
\text { (g/dL) }\end{array}$ & $\begin{array}{c}36.68 \\
\pm 1.32^{\mathrm{a}}\end{array}$ & $\begin{array}{l}35.06 \\
\pm 1.46^{\mathrm{a}}\end{array}$ & $\begin{array}{c}31.94 \\
\pm 1.37^{\mathrm{b}}\end{array}$ & $\begin{array}{c}30.06 \\
\pm 1.45^{\text {b }}\end{array}$ & $\begin{array}{c}31.22 \\
\pm 1.17^{\mathrm{b}}\end{array}$ & $\begin{array}{c}30.10 \\
\pm 1.08^{\mathrm{b}}\end{array}$ & $\begin{array}{c}30.53 \\
\pm 0.85^{\mathrm{b}}\end{array}$ & $\begin{array}{c}26.14 \\
\pm 0.84^{\mathrm{c}}\end{array}$ \\
\hline $\begin{array}{c}\text { WBCs } \\
\left(\times 10^{3} / \mu \mathrm{L}\right)\end{array}$ & $\begin{array}{l}55.02 \\
\pm 0.24^{\mathrm{c}}\end{array}$ & $\begin{array}{r}61.60 \\
\pm 0.28^{c}\end{array}$ & $\begin{array}{c}60.72 \\
\pm 0.29^{\mathrm{a}}\end{array}$ & $\begin{array}{c}67.01 \\
\pm 0.34^{\mathrm{ab}}\end{array}$ & $\begin{array}{c}59.21 \\
\pm 0.28^{\mathrm{b}}\end{array}$ & $\begin{array}{c}67.22 \\
\pm 0.38^{\mathrm{ab}}\end{array}$ & $\begin{array}{c}59.38 \\
\pm 0.38^{\mathrm{b}}\end{array}$ & $\begin{array}{c}68.15 \\
\pm 0.32^{\text {a }}\end{array}$ \\
\hline
\end{tabular}

Data were presented as mean \pm S.E ( $\mathrm{n}=6$ fish). Values within a row with different superscripts differ significantly (Duncan Multiple Range Test, $\mathrm{P}<0.05$ ). RBCs, Red blood cells. Hb, Hemoglobin. Hct, hematocrit. $\mathrm{MCV}$, mean corpuscular volume, $\mathrm{MCH}$, mean corpuscular hemoglobin, $\mathrm{MCHC}$, mean corpuscular hemoglobin concentration, WBCs, white blood cells.

In the present study, the statistical analysis of the hematological indices in $O$. niloticus and S. galilaeus exhibited a significant influence (Table 4). A reduction in RBCs, Hb, Hct and MCV was recorded in the blood of O. niloticus and S. galilaeus from polluted sites, compared to relatively less polluted site S1. Comparing sites, S4 recorded the lowest RBCs, Hb, Hct, MCV, MCH, and MCHC in both fishes, while S1 reported the highest values of latter variables. Conversely, WBCs count in both fishes was significantly increased $(\mathrm{P}<0.05)$ at $\mathrm{S} 4$, as compared to $\mathrm{S} 1$ which is recorded the least WBCs count. The present results find support from numerous studies which shown that the peripheral RBCs, Hb, Hct and MCV of fish decreased due to exposure to different pollutants (Zutshi et al., 2010; Summarwar, 2012; Gupta and Chandra, 2014).

The present reduction in RBCs, Hct and $\mathrm{Hb}$ as well as the WBCs enhancement may be attributed to the presence of HM, which found to decrease the RBCs count through RBC lysis (Adekunle et al., 2007; Moharram et al., 2011). Also, Katalay and Parlak (2004) reported an alteration in the RBCs and WBCs of fish exposed to environmental pollutants. The present findings further support the hypothesis of Moharram et al. (2011) who reported an adaptive response of fish exposed to $\mathrm{HM}$ through increase WBCs count, hemodilution and impaired $\mathrm{Hb}$ synthesis, which eventually leads to hypochromic, macrocytic anaemic condition, and swelling of RBC, this attributed to hypoxic conditions demonstrated in the present study via gills degradation.. 
The investigation of biochemical constituents of blood is a fundamental tool in the physiological and pathological assessment of fish to understand the toxicological impacts of xenobiotics (Li et al., 2011). Blood glucose levels, protein, and lipid profile of fishes act as good biomarkers of fish exposed to HM under field conditions (Javed and Usmani, 2013; salaah et al., 2018). Serum glucose, total protein, albumin, and total lipids levels of $O$. niloticus and $S$. galilaeus are shown in Table (5). In the present study, significant increase $(\mathrm{P}<0.05)$ was illustrated in mentioned serum metabolites in both fish species at different sampling site from Lake Nasser especially at S4.

Table (5): The biochemical parameters and blood electrolytes of $O$. niloticus and $S$. galilaeus from Lake Nasser.

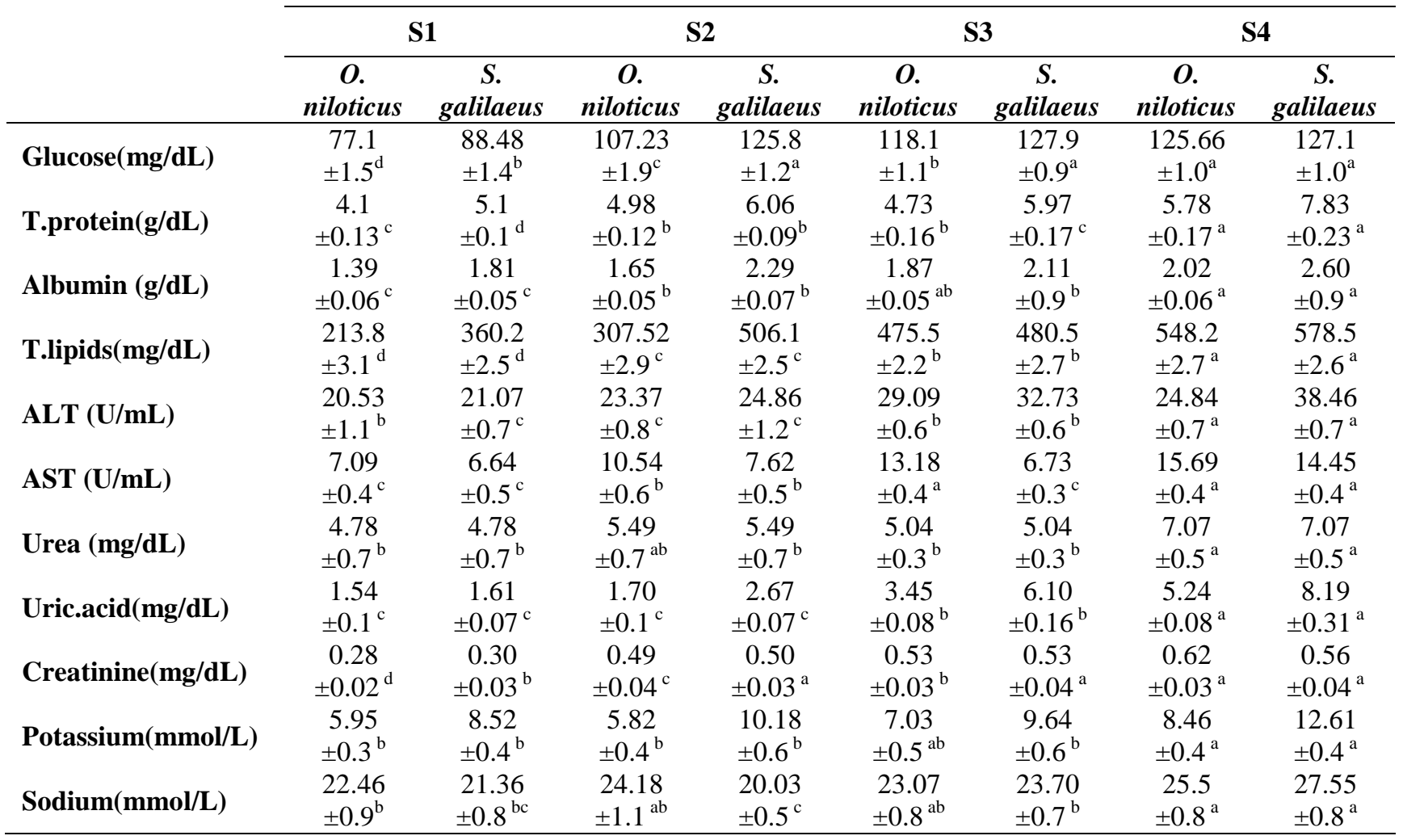

Data were presented as mean \pm SE ( $n=6$ fish). Values within a row with different superscripts differ significantly (Duncan Multiple Range Test, $\mathrm{P}<0.05$ ). T.; total, ALT; Alanine aminotransferase, AST; aspartate aminotransferase.

The blood glucose level variations are used as an indicator of stress response in fish (Kumar et al., 2016). However, water pollutants may be attributed to the present hyperglycemia, since HM known to modulate the carbohydrate metabolism in fish and stimulates the synthesis of glucose from extrahepatic tissue such as proteins and amino acids (Osman $\boldsymbol{e t}$ al., 2010). Moreover, animals inhabiting stressful environment produce more glucose for energy to cope with stress (Jentoft et al., 2005). Also the present 
hyperglycemia_may refer to liver malfunction/damage or renal dysfunction which is opined by the present findings.

Serum proteins are the main contributors in HM transportation (Bal $\boldsymbol{e t}$ al., 2013). Therefore, the impact of pollutants on serum total protein has been used to evaluate fish response to various stressors (Hadi et al., 2009). However, the major protein of blood is albumin which plays a critical role in the circulation of physiological, exogenous and endogenous chemicals, it also regulates blood osmotic pressure (Baker, 2002). Since the majority of serum proteins manufactured in the liver, according to the pathological finding of the present study, the increase in serum total protein and albumin reflects liver dysfunction which increases protein synthesis in liver due to HM pollution (Osman $\boldsymbol{e t}$ al., 2018; Salaah et al., 2018)

The present hyperlipidemia in both fish species from polluted sites may attribute to the current reported disorder of liver function and lipid metabolism. Lipids are important constituent of cell membrane which maintains cell fluidity, so membrane damage by HM could be another possible cause of the hyperlipidemia (Javed et al., 2017). According to Vaseem et al. (2013) when exposed to stress of HM toxicity fish increased the lipid mobilization to compete the growing demand for energy, this is in accordance with the present hyperglycemic response.

Liver functions: ALT and AST are valuable biomarkers which frequently used in the diagnosis of damage caused by pollutants in several tissues, for instance liver, gills, and muscle (De la Tore et al., 2000; Osman et al., 2010).

Serum ALT and AST were significantly increased $(\mathrm{P}<0.05)$ in $O$. niloticus and $S$. galilaeus from S2, S3, and especially S4 when compared to S1. Similar increase have been observed in plasma and serum of fish exposed to HM due to the injury of hepatocytes which consequently caused the leakage of these cytosolic enzymes into the bloodstream (Harvey et al., 1994; Salaah et al., 2018).

The kidney is known to play a significant part in the detoxification and discharge of toxicants. Urea, uric acid, and creatinine are non-protein nitrogenous compounds, while creatinine is a waste product mainly from muscles breakdown, urea is the major metabolite from dietary protein and tissue protein turnover. While, uric acid in fish is formed from exogenous and endogenous purines then converted in the liver to urea and excreted by the gills (Ajeniyi and Solomon, 2014). Urea, uric acid, and creatinine are useful in diagnosis of renal dysfunction, muscle damage, and nitrogen metabolism impairment (Murray et al., 1990).

In the present study urea, uric acid, and creatinine concentrations were significantly increased $(\mathrm{P}<0.05)$ in blood serum of both fish species gathered from different sites of Lake Nasser, especially at S4. Such increase was reported previously in fish exposed to HM (Abdel-Khalek, 2015). The present azotemia caused by HM, which characterized by low blood flow and filtration rate, while diagnosed by high levels of serum urea, uric acid, and creatinine (Chang et al., 1996). 
In fish, the sodium $\left(\mathrm{Na}^{+}\right)$and potassium $\left(\mathrm{K}^{+}\right)$are the main electrolytes; $\mathrm{K}^{+}$is the dominant in extracellular fluids and $\mathrm{Na}^{+}$in the serum and in other fluids. The electrolytes main function is to maintaining the acid-basic balance (Tavares-Dias et al., 2008). Furthermore, the homeostatic mechanism of fish is commonly trailed the aquatic ecosystem alterations, therefore electrolytes have been used as quantitative indicators of contamination in an ecosystem (Brewer $\boldsymbol{e t}$ al., 2001). Disease, stress and gill injury usually alters osmoregulation in fish through affecting gill permeability of ions (McDonald and Milligan, 1997).

The levels of blood serum electrolytes $\left(\mathrm{Na}^{+}\right.$and $\left.\mathrm{K}^{+}\right)$in the present study were significantly elevated $(\mathrm{P}<0.05)$ at $\mathrm{S} 4$ in both fish species, comparing to other sites. According to Zaki et al. (2001) higher $\mathrm{Na}^{+}$and $\mathrm{K}^{+}$levels may be a sign of kidney and gill damage, which may have impaired the osmoregulatory capacity in fish. We agree with this hypothesis, since blood electrolytes in the present study are in line with HM levels and the current pathophysiological changes in fish from different sampling sites.

\section{Histopathological findings:}

The liver is considered as the master of detoxification in vertebrates and particularly in fish. Liver is responsible for cleaning up the blood from xenobiotics. In the present study, liver of $O$. niloticus at S2 and S4 showed degeneration and necrosis in blood vessel and hepatocytes in Fig. (1, A-B). On the other hand, the results showed degeneration, necrosis, hemorrhage, and hemolysis in blood vessel, and degeneration hepatocytes in $S$. galilaeus collected from S2 and S4 (Fig. 1, C-D). Moreover, liver of S. galilaeus collected S3 cleared degeneration, balloon necrosis in hepatocytes, and dilation and hemorrhages in blood vessels (Fig. 1, E).

The gills participate in many important functions in fish, such as respiration, osmoregulation, and excretion. Gills are vulnerable to the water quality fluctuations as it's in direct contact with the external environment; also it considered the primary target of the contaminants (Fernandes and Mazon, 2003). Gills are formed of primary lamellae or gill filament and secondary lamellae, which found laterally from the primary lamellae. The surface of the gill lamellae is covered with epithelial cells running parallel along the surface. Injuries and pathological abnormalities frequent occur in gills due to xenobiotics whether dissolved or suspended in water which suppresses respiration by reducing the surface area (Tayel $\boldsymbol{e t}$ al., 2013).

Gills of $O$. niloticus obtained from S2 and S4 showed degeneration and severe necrosis in primary and secondary lamellae and hemorrhage in secondary lamellae (Fig. 2, A-B). In S. galilaeus collected from S2 and S4, gills showed degeneration, severe necrosis and separation in both primary and secondary lamellae, as well as hyperplasia, which lead to fusion of filament and curling of lamellae epithelial cells illustrated in Fig. (2, C-D), also a sever hemorrhages in primary lamellae showed in gills of S. galilaeus from S4 (Fig. 2, E). 
The muscular system is the main portion of the teleost body; it's responsible for locomotion, blood pumping and peristaltic constriction of viscera. On the other hand, fish would probably be invaded by micro-organisms when they have epithelial lesions in polluted water (Kadry et al., 2015). The present pathological changes observed in muscles of both fish species from different sampling sites including: Degeneration, necrosis, and edema in muscle fiber. In O.niloticus, degeneration and necrosis was observed in samples from S2 and S4 (Fig. 3, A-B). While, S. galilaeus collected from S2 and S4 showed dilation, hemorrhages in blood vessels, and fatty cells in hypodermal layer (Fig. 3, C-D), also showed necrosis in muscle fiber and fatty cells in hypodermal layer of fish samples from S3 (Fig. 3, E). However, the present study demonstrated that the fish inhabiting S4 (Khor El-Ramla) are more affected by water polluted (HM) than fish from other sampling sites. Moreover, $S$. galilaeus showed more severe cases than $O$. niloticus, this illustrated by higher level of HM bioaccumulation and MPI in S. galilaeus than O.niloticus.

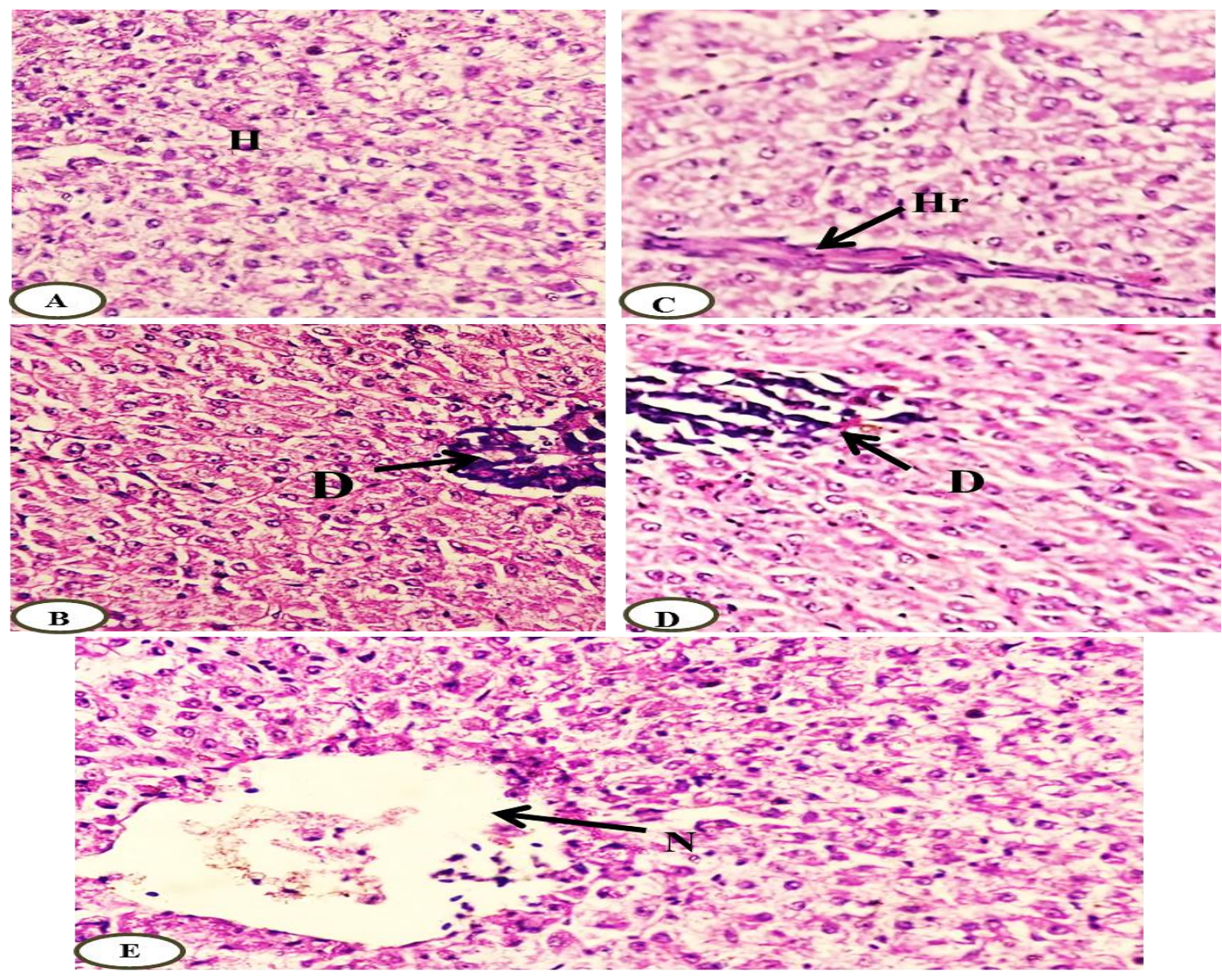

Figure (1): Photomicrograph of liver section of $O$. niloticus from S2 and S4 (A and B), $S$. galilaeus from S2, S3 and S4 (C, D and F). Hepatocytes $(H)$, Necrosis $(\mathrm{N})$, Degeneration (D), Hemorrhage (H). 


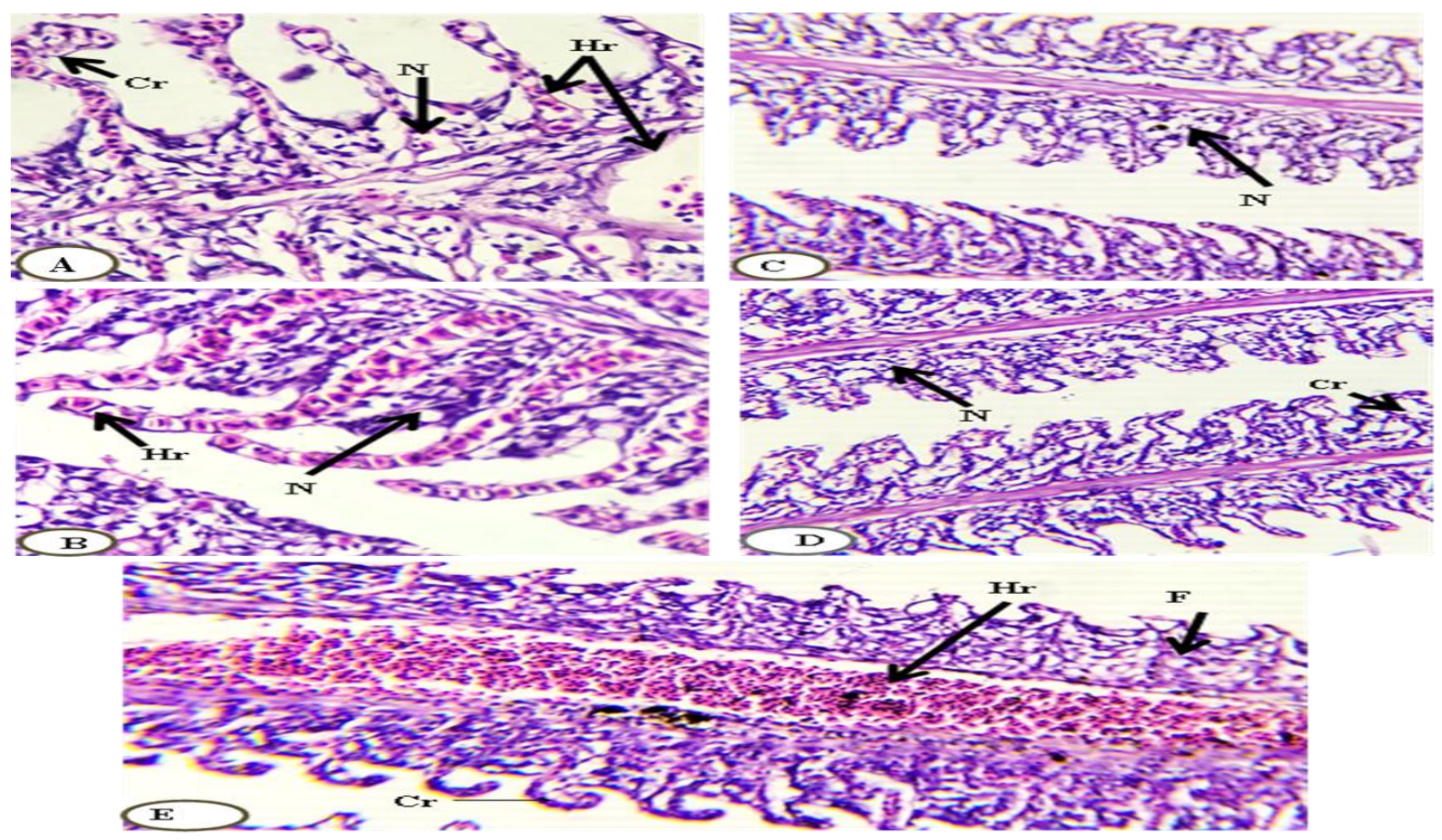

Figure (2): Photomicrograph of gill section of O. niloticus from S2 and S4 (A and B), S. galilaeus from S2 and S4 (C, D and E). Necrosis (N), Hemorrhage (H), Fusion (F), Curling $(\mathrm{Cr})$.

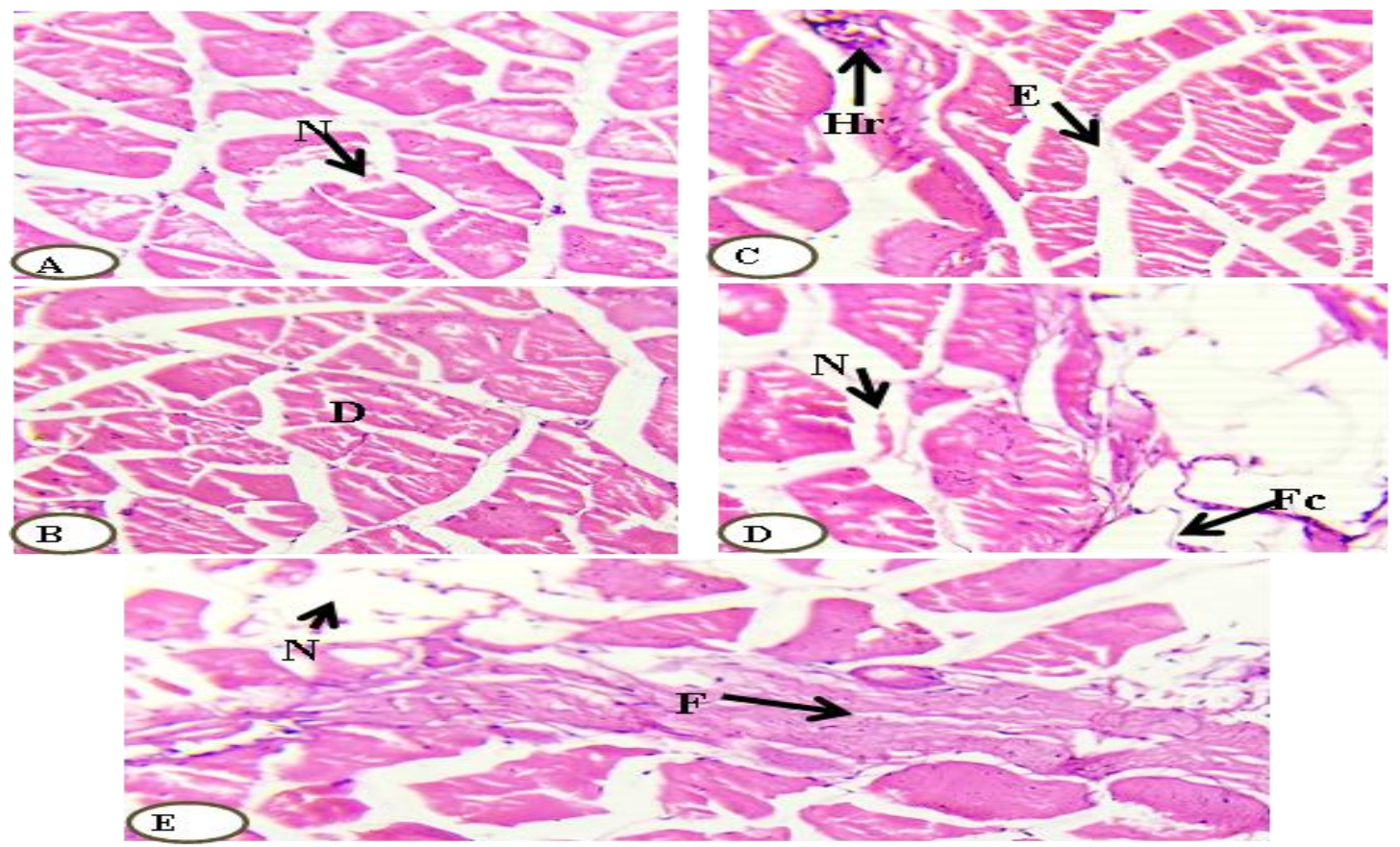

Figure (3): Photomicrograph of muscle section of O. niloticus from S2 and S4 (A and B), S. galilaeus from S2, S3 and S4 (C, D and F). Necrosis (N), Degeneration (D), Hemorrhage (Hr). Degeneration (D), Fatty cell $(\mathrm{Fc})$. 


\section{CONCLUSION}

The hematological and physiological alterations along with histopathological findings in $S$. galilaeus and $O$. niloticus from different sites of Lake Nasser indicated poor fish health and susceptibility to diseases. This may attribute to the dramatic change in fish production, distribution and diversity of fish in Lake Nasser. The present data supports the hypothesis that fish species is a critical concern in routine application for bio-monitoring scopes. Since $S$. galilaeus reported inferior hematological indices and higher MPI, as well as worst liver and kidney function and sever histopathological changes, when compared to $O$. niloticus collected from the same sites of Lake Nasser. This opined that $S$. galilaeus are more resistant than $O$. niloticus to environmental stress, while $O$. niloticus are more sensitive to aquatic pollutants. Moreover there was an adverse health effects for habitual consumers of both fish species from S4 (Middle of Khor ElRamla).

\section{ACKNOWLEDGMENT}

We would like to thank prof. Soaad A. Mahmoud, proffesor of fish pathology (NIOF), for the special support in the Histological study.

\section{REFERENCES}

Abdel-Khalek, A.A.; Kadry, M.A.; Badran, S.R. and Marie, M.A.S. (2015). Comparative toxicity of copper oxide bulk and nano particles in Nile tilapia; Oreochromis niloticus: biochemical and oxidative stress. J. Basic Appl. Zool., 72: 43-57.

Adekunle, I.M.; Arowolo, T.A.; Omoniyi I.T. and Olubambi, O.T. (2007). Risk assessment of Nile Tilapia (Oreochromis niloticus) and African mud catfish (Clarias gariepinus) exposed to cassava effluent. Chem. Ecol., 23: 383-392.

Agrama, A. (2014). Assessment of Contamination in Sediments of Lake Nubia in Sudan. Nile Water Sci. Eng. J., 7(1).

Ajeniyi S.A. and Solomon R.J. (2014) Urea and creatinine of Clarias Gariepinus in three different commercial ponds. Nat. Sci., 12:124-138.

Al-Busaidi, M.; Yesudhason, P.; Al-Mughairi, S.; Al-Rahbi, W.A. K.; Al-Harthy, K. S.; AlMazrooei, N.A. and Al-Habsi, S.H. (2011). Toxic metals in commercial marine fish in Oman with reference to national and international standards. Chemosphere., 85(1): 6773.

Ali, S.M.; Othman, A.A. and Abbas, M.T. (2016). Bacteriological monitoring for the Northern Khors of Lake Nasser, Egypt. Microbiol., 11(2-3): 80-92.

Baker, M.E. (2002). Beyond carrier proteins: albumin, steroid hormones and the origin of vertebrates. J. Endocrinol., 175: 121-127.

Bal, W.; Sokołowska, M.; Kurowska, E. and Faller, P. (2013). Binding of transition metal ions to albumin: sites, affinities and rates. Biochem. Biophys. Acta. (BBA)-General Subjects., 1830(12): 5444-5455. 
Bayomy, M.F.F.; Alne-na-ei, A.A.; Gaber, H.S.; Sayed, H.A. and Khairy, D.M. (2015). Environmental and physiological impacts of heavy metals on Nile Tilapia (Oreochromis niloticus). J. Biosci. Appl. Res., 1:52-58.

Bishai, H.M.; Abdel-Malek, S.A. and Khalil, M.T. (2000). Lake Nasser. Publication of National Biodiversity Unit, No. 11, Egyptian Environmental Affairs Agency, Egypt, 577 pp.

Blaxhall, P.C. and Daisley, K.W. (1973). Routine haematological methods for use with fish blood. J. fish Biol., 5(6):771-81.

Brewer, S.K.; Little, E.E.; Delonay, A.K.; Beavais, S.L.; Jones, S.B. and Ellersieck, M.R. (2001). Behavioural dysfunctions correlate to altered physiology in rainbow trout (Oncorhynchus mykiss) exposed to cholinesterase inhibiting chemicals. Arch. Environ. Contam. Toxicol., 40:70-76

Castro-González, M.I. and Méndez-Armenta, M. (2008). Heavy metals: Implications associated to fish consumption. Environ. toxicol. pharmacol., 26(3): 263-271.

Çelik, M.Y.; Karayücel, S.; Karayücel, İ; Öztürk, R. and Eyüboğlu, B. (2012). Meat yield, condition index, and biochemical composition of mussels (Mytilus galloprovincialis Lamarck, 1819 in Sinop, South of the Black Sea. J. Aquat. food prod. Technol., 21(3):198-205.

Chang, L.W.; Magos, L. and Suzuki, T. (1996). Toxicology of metals. Taylor and Francis US. CRC press., 977-1001 pp.

Copat, C.; Bella, F.; Castaing, M.; Fallico, R.; Sciacca, S. and Ferrante, M. (2012). Heavy metals concentrations in fish from Sicily (Mediterranean Sea) and evaluation of possible health risks to consumers. Bull. Environ. Conta. Toxicol., 88(1): 78-83.

Darwish, M.A.G. (2013). Geochemistry of the High Dam Lake sediments, South Egypt: implications for environmental significance. Int. J. Sedim. Res., 28: 544-559.

De la Tore, F.R.; Salibian, A. and Ferrari, L. (2000). Biomarkers assessment in juvenile Cyprinus carpio exposed to waterborne cadmium. Environ. Pollut., 109:227-278.

Doumas, B.T.; Watson, W.A. and Biggs, H.G. (1971). Albumin standards and the measurement of serum albumin with bromcresol green. Clinica. chimica. acta., 31(1):87-96.

El-Far, A.; Aly, W.; El-Haweet, A. E.; Nasr-Allah, A. and Karisa, H. (2020). Fisheries management based on gear selectivity of a tropical reservoir, Lake Nasser, Egypt. Egypt. J. Aquat. Res., 46 (1): 71-77.

El-Shabrawy, G.M. (2014). Ecological Basis for Lake Nasser Ecosystem. Lap Lambert Academic Publishing, Norderstedt, Germany., 269.

El-Shabrawy, G.M. and Dumont H.J. (2003). Spatial and seasonal variation of the zooplankton in the coastal zone and main khors of Lake Nasser (Egypt). Hydrobiologia, 491: 119132.

Fernandes, M.N. and Mazon, F. (2003). Environmental pollution and fish gill morphology. Fish adaptation, 203-231.

Firat, Ö. and Kargın, F. (2010). Individual and combined effects of heavy metals on serum biochemistry of Nile tilapia Oreochromis niloticus. Archives Environ. Contamin. toxicol., 58(1); 151-157. 
Frings, C.S. and Dunn, R.T. (1970). A colorimetric method for determination of total serum lipids based on the sulfo-phospho-vanillin reaction. American J. Clinica. Pathol., 53(1): 89-91.

Ghazaly, K.S. (1988). The bioaccumulation of potential heavy metals in the tissues of the Egyptian edible marine animals. Part 1. Crustaceans. Bull. Natl. Inst. Oceanogr. Fish., 14: 71-77.

Gupta, S.K.; Pal, A.K.; Sahu, N.P.; Saharan, N.; Prakash, C.; Akhtar, M.S. and Kumar, S. (2014). Haemato-biochemical responses in Cyprinus carpio (Linnaeus, 1758) fry exposed to sub-lethal concentration of a phenylpyrazole insecticide, fipronil. Proceedings of the national academy of sciences, India section b: Biol. Sci., 84(1): 113-122.

Hadi, A.; Shokr, A. and Alwan, S. (2009). Effects of aluminium on the biochemical parameters of fresh water fish Tilapia zillii. J. Sci. Appl., 3(1): 33-41.

Harvey, R.B.; Kubena, L.F. and Elissalde, M. (1994) Influence of vitamin E on aflatoxicosis in growing swine. Am. J. Vet. Res., 55:572-577.

Heikal, M.T. (2010). Impact of water level fluctuation on water quality and trophic state of Lake Nasser and its Khors, Egypt. Egypt. J. Aquat. Biol. Fish., 14: 75-86.

Hrubec, T.C.; Cardinale, J.L. and Smith, S.A. (2000). Hematology and plasma chemistry reference intervals for cultured tilapia (Oreochromis hybrid). Vet. Clin. Pathol., 29(1):712.

Hussein, W.O. and El Shafi, E.A. (2005). Environmental study on water quality assessment and prediction in Nasser Lake by using monitoring networks. Ninth International Water Technology Conference, IWTC9 2005, Sharm El-Sheikh, Egypt.

IFCC (1986). International Federation of Clinical Chemistry. Biochem. J. Clin. Chem. Clin., 24 (7): 497-510.

Jarić, I.; Višnjić-Jeftić, Ž.; Cvijanović, G.; Gačić, Z.; Jovanović, L; Skorić, S. and Lenhardt, M. (2011). Determination of differential heavy metal and trace element accumulation in liver, gills, intestine and muscle of sterlet (Acipenser ruthenus) from the Danube River in Serbia by ICP-OES. Microchem. J., 98(1): 77-81.

Javed, M. and Usmani, N. (2013). Assessment of heavy metal ( $\mathrm{Cu}, \mathrm{Ni}, \mathrm{Fe}, \mathrm{Co}, \mathrm{Mn}, \mathrm{Cr}, \mathrm{Zn})$ pollution in effluent dominated rivulet water and their effect on glycogen metabolism and histology of Mastacembelus armatus. SpringerPlus., 2(1): 390.

Javed, M.; Ahmad, M.I.; Usmani, N. and Ahmad, M. (2017). Multiple biomarker responses (serum biochemistry, oxidative stress, genotoxicity and histopathology) in Channa punctatus exposed to heavy metal loaded waste water. Scientific reports., 7(1): 1-11.

Jentoft, S.; Aastveit, A.H.; Torjesen, P.A. and Andersen, Ø. (2005). Effects of stress on growth, cortisol and glucose levels in non-domesticated Eurasian perch (Perca fluviatilis) and domesticated rainbow trout (Oncorhynchus mykiss). Comparative Biochemistry and Physiology Part A: Molecul. Integrat. Physiol., 141(3): 353-358.

Kadry, S.M.; Tayel, S.I.; Afify, M.F. and El-Sayed, R.A. (2015). Ecohistopathological studied on Oreochromis niloticus fish living in Damietta Branch in Egypt. World J. Pharm. Sci., 3(5): $815-825$. 
Katalay, S. and Parlak, H. (2004). The Effects of Pollution on Haematological Parameters of Black Goby (Gobius niger L., 1758) in Foça and Aliağa Bays. Su Ürünleri Dergis., 21(1).

Khalifa, U.S.; Agaypi M.Z. and Adam H.A. (2000). The Population Dynamics of Oreochromis niloticus L. and Sarotherodon galilaeus Art. In: Sustainable Fish Production in Lake Nasser: Ecological Basis and Management Policy, Craig, J.F. (Ed.). Vol. 61, ICLARM, Penang, Malaysia., 87-90.

Kumar, R.B.; Goren, N.D.; Stark, D.E.; Wall, D.P. and Longhurst, C.A. (2016). Automated integration of continuous glucose monitor data in the electronic health record using consumer technology. J. America. Med. Informat. Assoc., 23(3):532-537.

Latif, A.F.A. (1976). Fishes and fisheries of Lake Nasser. In The Nile, Biology of an Ancient River. Springer, Dordrecht., 299-307.

Latif, A.F.A. (1984). Lake Nasser. The new man-made lake in Egypt (with reference to Lake Nubia). In El-Serveir, F. B. T. (ed.), Ecosystems of the World 32, Lakes and Reservoirs., $385-416 \mathrm{pp}$.

Li, Z.H.; Velisek, J.; Grabic, R.; Li, P.; Kolarova, J. and Randak, T. (2011). Use of hematological and plasma biochemical parameters to assess the chronic effects of a fungicide propiconazole on a freshwater teleost. Chemosphere. 83: 572-578.

Loska, K. and Wiechuła, D. (2003). Application of principal component analysis for the estimation of source of heavy metal contamination in surface sediments from the Rybnik Reservoir. Chemosphere., 51(8): 723-733.

McDonald, G. and Milligan, L. (1997). Ionic, osmotic and acid-base regulation in stress. Fish stress and health in aquaculture., 62: 119-145.

Moharram, S.G.; Wahbi, O.M. and El-Greisy, Z.A. (2011). Effect of polluted water from the Egyptian Eastern Mediterranean coast on reproductive, toxicological and hematological characteristics of Siganus rivulatus. Pakistan J. Biol. Sci., 14(12): 668.

Murray, R.K.; Granner, D.K.; Mayes, P.A. and Rodwell, V.W. (1990). Enzyme kinetics. Harpers Biochemistry, Mc Graw Hill Inc., Mexico City, Mexico., 68-81.

Ntakirutimana, T.; Du, G.; Guo, J.S.; Gao, X. and Huang, L. (2013). Pollution and Potential Ecological Risk Assessment of Heavy Metals in a Lake. Polish J. Environ. Studies., 22(4).

Nussey, G.; Van Vuren, J.H.J. and Du Preez, H.H. (1995). Effect of copper on the haematology and osmoregulation of the Mozambique tilapia, Oreochromis mossambicus (Cichlidae). Comparative Biochemistry and Physiology Part C: Pharmaco., Toxicol. Endocrinol., 111(3): 369-380.

Osman, A.G., Abd-El-Baset, M., AbuelFadl, K.Y. and GadEl-Rab, A.G. (2010). Enzymatic and histopathologic biomarkers as indicators of aquatic pollution in fishes. Nat. Sci., 2(11): 1302.

Osman, A.G.; AbouelFadl, K.Y.; Abd El Baset, M.; Mahmoud, U.M.; Kloas, W. and Moustafa, M.A. (2018). Blood Biomarkers in Nile tilapia Oreochromis niloticus and African Catfish Clarias gariepinus to Evaluate Water Quality of the River Nile. J. Fish. Sci. comp., 12(1): 1-15. 
Papagiannis, I.; Kagalou, I.; Leonardos, J.; Petridis, D. and Kalfakakou, V. (2004). Copper and zinc in four freshwater fish species from Lake Pamvotis (Greece). Environ. int., 30(3): 357-362.

Salaah, S.M., Khalil, M.T., Gad, N.S. and Ahmed, N.A.M. (2018). Physico-chemical characteristics and physiological changes in Oreochromis Niloticus from Rosetta branch of The River Nile. Europ. Chem. Bull., 7(2): 63-71.

Shah, S.L. and Altindag, A. (2004). Hematological parameters of tench (Tinca tinca L.) after acute and chronic exposure to lethal and sublethal mercury treatments. Bulletin of environ. Conta. toxicol., 73(5):911-918.

Sivaperumal, P., Sankar, T.V. and Nair, P.V. (2007). Heavy metal concentrations in fish, shellfish and fish products from internal markets of India vis-a-vis international standards. Food chem., 102(3): 612-620.

Summarwar, S. (2012). Comparative haematological studies of Clarius batrachus in Bisalpur reservoir and Pushkar Lake. Indian J. Fundamental Appl. Life Sci., 2: 230-233.

Sunderman, Jr. F.W. and Sunderman, F.W. (1958). Colorimetric determination of potassium in serum and plasma. Am. J. Clin. Pathol., 29: 95.

Suvetha, L.; Ramesh, M. and Saravanan, M. (2010). Influence of Cypermethrin toxicity on ionic regulation and gill $\mathrm{Na}+\mathrm{K}+\mathrm{ATPase}$ activity of a freshwater teleost fish Cyprinus carpio. Environ. toxicol. Pharmacol. 29 (1):44-49.

Tavares-Dias, M.; Moraes, F.R. and Martins, M.L. (2008). Hematological assessment in four Brazilian teleost fish with parasitic infections, collected in feefishing from Franca, São Paulo, Brazil. Boletim do Instituto de Pesca., 34(2): 189-196.

Tayel, S.A.; Mahmoud, S. and Ahmed, A.M. (2018). Pathological impacts of environmental toxins on Oreochromis niloticus fish inhabiting the water of Damietta branch of the River Nile, Egypt. Egypt. J. Aquat. Biol. Fish., 22(5):309-321.

Tayel, S.I.; Ibrahim, S.A. and Mahmoud, S.A. (2013). Histopathological and muscle composition studies on Tilapia zillii in relation to water quality of Lake Qarun, Egypt. J. Appl. Sci. Res., 9(6): 3857-3872.

Tietz, N.W. (1986). Blood urea and creatinine concentrations. Textbook of Clinical Chemistry, 1$386 \mathrm{pp}$.

Tietz, N.W. (1990). Clinical Guide to Laboratory Tests 2nd Ed. Philadelphia. Tovar D, Zambonino-Infante JL, Cahu C, Gatesoupe FJ, Vzquez-rez R, Lésel R (2002). Effect of live yeast incorporation in compound diet on digestive enzyme activity in sea bass larvae. Aquacult., 204:113-123.

Tietz, N.W. (1994). Total protein in clinical guide to laboratory Tests., 610-611.

Tietz, N.W.; Finley, P.R. and Pruden, E.L. (1995). General clinical tests. Clinical Guide to Laboratory Tests. WB Saunders, USA., 3:577-580.

Trinder, P. (1951). A rapid method for the determination of sodium in serum. Analyst., 76(907):596-599.

USEPA (2000). United States Environmental Protection Agency. Guidance for Assessing Chemical Contaminant Data for Use in Fish Advisories, vol. 2, Risk Assessment and Fish Consumption Limit, EPA/823/B-97/009, Office of Science and Technology and Office of Water, Washington, DC, USA, 3rd edition. 
USEPA (2002). United States Environmental Protection Agency. Region 9, Preliminary Remediation Goals, Region 9 PRGs Table 2002 Update, United States Environmental Protection Agency.

USEPA (2015). United States Environmental Protection Agency "Human health risk assessment, risk-based screening table, regional screening level (RSL) summary table," http:// semspub.epa.gov/work/03/2218434.pdf.

Vaseem, H. and Banerjee, T.K. (2013). Contamination of the River Ganga and its toxic implication in the blood parameters of the major carp Labeo rohita (Ham). Environ. sci. pollut. res., 20(8); 5673-5681.

WHO. (1989). World Health Organization. Heavy metals-environmental aspects; Environment health criteria. No.85. Geneva, Switzerland.

Yacoub, A.M., and Gad, N.S. (2012). Accumulation of some heavy metals and biochemical alterations in muscles of Oreochromis niloticus from the River Nile in Upper Egypt. Int. J. Environ. Sci. Eng., 3:1-10.

Zaki, M.S.; Sharaf, N.E. and Osfor, H.M. (2007). Effect of vanadium toxicity on biochemical, haematological and clinicopathological changes in Clarias lazera present in the River Nile. American-Eurasian J. Agric. Environ., 2:741-745.

Zhao, H.; Xia, B.; Fan, C.; Zhao, P. and Shen, S. (2012). Human health risk from soil heavy metal contamination under different land uses near Dabaoshan Mine, Southern China. Sci. Total Environ., 417:45-54.

Zutshi, B.; Prasad, S.R. and Nagaraja, R. (2010). Alteration in haematology of Labeo rohita under stress of pollution from Lakes of Bangalore, Karnataka, India. Environ. Monitoring and assessment. 168(1-4): 11-19. 